\title{
ELECTORAL CHOICE \& PRACTICE AND THE DEMOCRATIC PROCESS IN MOZAMBIQUE
}

\author{
By \\ Obede Baloi \\ Dr Obede Suarte Baloi is Dean of the Faculty of Social Sciences, Eduardo Mondlane University, \\ Maputo, Mozambique
}

\section{INTRODUCTION}

Elections, which constitute the basis of the concept and practice of modern liberal democracies, have a twofold significance: they serve as a tool for legitimating the political regime and they provide the main forum for both political competition and popular political participation. In both cases they help to secure popular control over government - the principal characteristic of a democratic representative system of government (Beetham and Boyle 1995).

Modern liberal democracies are basically representative political systems. This amounts to saying that a modern democratic government is legitimate to the extent that it has been constituted through some sort of expressed choice by the bulk of the citizenry. From Locke to Rousseau, from James Madison to Schumpeter, a democratic government is described as one that bears a popular mandate, obtained through several and distinct ways of amalgamating the popular will.

To be sure, as Schumpeter and a number of social choice theorists (notably William H. Riker 1982) stress, one important defining feature of modern democracies is that individuals acquire decision-making powers through a competitive struggle for the people's vote (Schumpeter 1954). This feature links elections with a particular institutional setting, namely that of a multi-party political system. This qualification is relevant because it is possible for elections to take place and political participation to be encouraged outside the realm of modern liberal and representative forms of democratic governments with a view to legitimating a particular political regime. Beetham and Boyle's 'democratic pyramid' encompasses, apart from elections, civil and political rights, a strong civil society and an accountable government, all of which find expression in a well functioning pluralistic political system (Beetham and Boyle 1995).

There are obviously other relevant forms of popular political participation, among them membership of political parties, pressure groups and different social movements, as well as activities designed to influence public opinion in a desired direction. However, these forms of participation require a certain degree of political 
sophistication and awareness, mostly associated with levels of education, access to the means of mass communication, the existence of strong civil society networks and the nature of the prevalent political culture in a given society. In many countries these are scarce resources, both in terms of the general level of information and understanding and, specifically, in terms of political knowledge. Thus, in countries such as Mozambique, elections are the principal means of guaranteeing popular political participation.

In such circumstances, electoral systems are part of the main political institutions of democratic political systems. In fact, electoral systems constitute the mechanism through which norms and regulations are established that determine both how political preferences are expressed in a given society and how votes obtained in any given election are turned either into parliamentary seats or government positions. In other words, electoral systems influence both citizens' political behaviour and electoral results. Furthermore, they shape both the degree of political representation in a given political system and the character of the party system (Carrilho 1996).

For these reasons it is relevant to reflect on how electoral models and practices influence the development of the democratic process. This is even more so in countries such as Mozambique that are not only in the early stages of democratisation but are also emerging from a lengthy period of political confrontation and civil unrest. In the following pages this paper will approach the issue of the choice of the electoral model and its practice from two distinct standpoints - the choice between representativeness and governability, and the possible or desired balance between political competition and popular political participation. In both cases the discussion will bear in mind that the issue is not merely theoretical, it is a concrete reflection of the problems facing a democratising country emerging from a destructive war that not only created deep rivalries between important groups in society but also destroyed the sense of trust and common purpose among the population.

\section{Choosing the Electoral Model}

It cannot be doubted that electoral systems are not neutral. Because they are not neutral, choosing one of them is also not innocuous. It is not a mere technical problem - knowing how best to translate the votes cast by the electorate into parliamentary seats.

Carrilho 1996

Two important points of departure for assessing and understanding the choice of an electoral model for Mozambique are to be found in the prevalent electoral culture of post-independence Mozambique, and the dominance of Frelimo and Renamo over the political landscape of the country. These points are institutionally related, and indeed formally represented, by the two main sources of the electoral law of 
Mozambique - the 1990 Political Constitution and the 1992 General Peace Agreement (Law 13/92 of 14 of October)(Tollenaere 2000).

The choice that had to be made was between a multi-party parliament representing a broad spectrum of political parties and an unfragmented parliament and a cohesive and strong executive. The question that had to be asked was what mattered most to each of the principal political players? Here it is worth noting that Mozambique (with an estimated population of 18 million inhabitants and about 8 million eligible voters) has 26 officially registered political parties. The first to be registered (on 19 August 1991) was Frelimo, which has ruled the country for 25 years, the last was the tiny worker and peasants' party PANAOC, registered on 12 March 1999. Renamo, the former guerrilla movement, was registered on 22 August 1994. By 1994, the year in which the first general multi-party elections were held, 18 political parties had been registered. Between then and the 1999 general election eight more parties were formed.

In the 1994 election two electoral coalitions were formed: the Patriotic Alliance (AP) comprising two parties, Monamo and FAP, and the Democratic Union Coalition (UD) comprising three parties advocating a federalist system of government Palmo, Panade and Panamo. While Monamo was formed around a veteran politician and lawyer, Dr Maximo Dias, FAP was a youth party created mainly by former graduates of the Eduardo Mondlane University. Parties in the UD coalition also had in common the fact that their leadership was drawn from former Frelimo cadres who had deserted the party, supposedly because they had failed to move up within the party's hierarchy. At the time, only one political party, PPLM, failed to participate in the election because of irregularities on its official documentation. So, participants in the 1994 elections included 12 parties and two coalitions. The possible balance between representativeness and governability has to be judged from the standpoint of this range of political expression.

During Mozambique's existence as a one-party state Frelimo established a system of government that rested on a strong presidency supported by the de facto dominance of the executive over all other branches of government. This was so despite the fact that in the 1975 Constitution it was stated that the Popular Assembly (then the National Assembly) constituted the supreme body of the state power. The cohesiveness of this system was guaranteed by the stipulation that the president of Frelimo was the automatic president of the country and the decision-making power was to be concentrated in the political commission (bureau) of the party. This system meant, in practice, that although there were elections between 1977 and 1986 (Monteiro 1988) in which the citizens had the opportunity to choose delegates for different levels of assemblies, in fact, it was the top leadership of the party that was responsible for the most important political decisions.

The point here is not to argue that the issue of representation was overlooked within the political practice of Frelimo. Indeed, the composition of the first Popular Assembly ensured a system of representation through which elements representing different segments of society (the mass democratic movements) were guaranteed 
automatic seats. However, while such a measure may well have worked as a tool for promoting political awareness among the citizenry it was not a relevant intervening factor in the governability of the country. In light of this it was no surprise that the 1990 Political Constitution approved by the then one-party Popular Assembly introduced the 'first-past-the-post' electoral system for both legislative and presidential elections.

However, the context of the Rome peace negotiations between Frelimo and Renamo and the specific nature of the General Peace Agreement signed in 1992 between these two opposing political forces meant that the disposition of the country's Constitution regarding the electoral system had to change. It is important to note that the General Peace Agreement stated that: 'The Government undertook not to promulgate any legislation contrary to the agreement reached' (Protocol I: Basic Principles). Until the 1994 general election this meant that the General Peace Agreement was de facto above the state Constitution and, thereafter, de jure submitted to it (Carrilho 1996).

Two aspects are worth mentioning in the context of the Rome negotiations. One relates to the natural distrust between two rival political forces that had been in conflict for nearly 16 years and, indeed, during the negotiation itself, were still conducting important military operations in the field. In this context it is not difficult to understand why each side would regard with considerable suspicion any proposal coming from the opposing camp.

The other aspect relates to the perception by Renamo of the relative political advantage of Frelimo in the country. Indeed, Frelimo not only fought the liberation struggle that brought independence to Mozambique, it was also the single party in power throughout. This led Renamo to consider that Frelimo had chosen the majority system in order to establish its dominance. Thus, in order to secure a future relevant representation in parliament Renamo opted for an electoral system based on proportional representation, through closed party lists, with the 11 provinces of the country as constituencies.

It is tempting to suggest that while Frelimo opted for governability rather than representativeness, Renamo did just the opposite. In fact, both parties (Renamo transformed itself from a guerrilla movement into a political party immediately after the Rome Peace Accord) opted for the system that appeared to them best able to secure their political interests. Independently of the choice made, at the conclusion of the first multi-party general election it became clear that, somewhat contrary to conventional wisdom, the proportional representation system as practised in Mozambique produced a party system closer to that associated with a system of majority vote. The election produced a strong parliamentary majority for Frelimo and a two-party system, although the Democratic Union Coalition of three small parties managed to secure 9 seats in parliament against 129 for Frelimo and 112 for Renamo. Interestingly, had the 'first-past-the-post' system been enacted as originally envisaged in the Constitution, Renamo would have secured a strong parliamentary majority, with 152 seats. The party secured a majority in 6 of the 11 provincial 
constituencies, including Zambezia and Nampula - by far the biggest constituencies in the country.

This is not the appropriate place to speculate about the reasons for this occurrence, but it can be said that Renamo underestimated the level of support it enjoyed in the country, particularly in the countryside. Another possible reason might have been that some voters opted for Renamo as a means of keeping the party within the wheels of the democratic process, thus preventing any possible return to war, starvation and mass destruction. Certainly important groups in society, notably religious entities, actively sought to mobilise voters to use their vote strategically, along the line of bipolar politics, to guarantee peace and reconciliation. Another possible intervening factor was the clear lack of institutional stability, territorial presence, organisational skills and material and financial resources among all political parties apart from the two main contenders. The culture of fear and the extreme deference to authority - strengthened by both pre-colonial and colonial-fascist modes of political exercise - can also shed some light on why the electoral battle was basically restricted to Frelimo and Renamo.

\section{Tension Between Peace Building AND THE Democratic Process}

A new democratic order in Mozambique meant, in a substantive sense, the institutionalisation of political competition. While it can be argued that under the one-party state meaningful popular political participation was encouraged, it must be added that it was a guided political participation, mostly designed to legitimate the political regime. Undoubtedly such practice introduced most Mozambicans to a world of individual freedoms not exercised under the colonial regime. Furthermore, at least at the lower levels of legislative power, the system allowed for citizens to have direct control over their representatives and delegates. In general terms, the system broadened the scope of political mobilisation, helping to construct and consolidate a sense of a common purpose among the citizenry, an element that had largely been destroyed by the lengthy period of armed confrontation. However, political competition was not part of the system.

Political competition was enshrined in the Constitution and stamped on the electoral law at the time when the country and its people were struggling to secure peace and begin a long and difficult process of national reconciliation. One of the main reasons why political competition had to be established relates to the nature of democratisation. This is a process that, according to Przeworski (1991) '... is an act of subjecting all interests to competition, of institutionalising uncertainty. The idea is that by institutionalising political competition power is effectively devolved from a group of people to a set of rules. And, through the mechanisms of a free vote 'the people have the opportunity of accepting or rejecting the men who are to rule them' (Schumpeter 1954). Political competition made possible by democratisation can best flourish in a context where there is a broad consensus on certain 
fundamental principles within society, such as the need to secure law and order, welfare, and the like. Conversely, where there are deep divisions within society, such as along ethnic, religious and/or racial lines, political competition can pose serious threats to the political order itself rather than contribute to the consolidation of democracy.

Thus, although it was stated in the first protocol concerning basic principles that 'Renamo committed itself to respect the laws and institutions of State', it was plain that the first general election could not have been conducted under the supervision of the existing institutional structure. In fact, it can be argued that the struggle of Renamo against the one-party state led by Frelimo was waged both against the party and against the state institutions themselves - an institution associated with the status quo ante could hardly command allegiance from the Renamo camp. Thus, in order to overcome the level of mutual distrust and in an effort to guarantee fairness and transparency in the electoral process, a new legal and institutional framework was set up to govern the first general multi-party election in the country. This framework comprised the National Elections Commission (CNE), the Technical Secretariat for Electoral Administration (STAE) and the Electoral Tribunal.

The National Elections Commission was to be the decision and supervisory body of the electoral process. It had 21 members -10 nominated by the government, 7 by Renamo, 3 by the other political parties, and a chairman chosen by consensus. Frelimo and Renamo each nominated a vice-chair, and the three main committees - the Organisation and Operations Committee, the Legal, Training and Civic Education Committee and the Administration and Finance Committee (CNE 1995) - were chaired by a representative of each political grouping. It is clear that both the party political choice that determined the creation of the CNE and the requirement of consensus in decision-making were measures designed to build confidence between the main political contenders and to overcome distrust, particularly that of Renamo, towards the institutions of the state.

The same logic was applied to the constitution of the Technical Secretariat for Electoral Administration - the body responsible for implementing all electoral activities. Thus, while its chairman was appointed by the government, his two deputies were nominated respectively by Renamo and the 'unarmed' opposition parties (a term then used to describe all parties except Frelimo and Renamo). It is important to note that, at the central level, STAE also included fifty specialists twenty-five nominated by government, thirteen by Renamo and twelve representing the United Nations System. This representation of the United Nations System was extended to the Electoral Tribunal - a body that had the power to hear appeals emanating from decisions of the CNE. Of the five members of the Electoral Tribunal, two were Mozambican judges nominated by the High Council of the Bench and three were foreign judges nominated by the United Nations (CNE 1995).

The presence of the United Nations during Mozambique's difficult democratic transition was of utmost importance in the drive towards finding a proper balance 
between the requirements of peace building and the normal rules of the democratic order. The same can be said of the donor community at large, which provided funding for the electoral process as well as humanitarian assistance programmes, including earmarked funding to be allocated to the contending political parties.

\section{Some Reflections on the Practice of the Chosen Electoral Model}

The major achievement of Mozambique's electoral platform was its ability to secure post-conflict peace building and national reconciliation. This success can be explained by three factors.

The first was the direct involvement of the United Nations System in almost all phases of the electoral process - it effectively functioned as a third enforcing body to the agreements reached.

Secondly, the de facto bipartisan role of the two main political contenders in the constitution and functioning of the electoral bodies contributed to easing the atmosphere of distrust and guaranteed a degree of political competition which was not destructive to the process of national reconciliation.

Finally, the force of civil society organisations also played a critical role. Indeed, the phenomenon of war fatigue and the desire for the country to make a new start led several civil society bodies to take the initiative to guarantee that the elections would consolidate rather that hamper the peace process.

Another important achievement was the limits imposed on political parties interested in taking an active role in the country's political process who were effectively prevented from forming factions, be it along regional, ethnic, linguistic, racial or religious lines. In sum, the parties were expected to concern themselves with national issues. The parties were effectively given a monopoly on the political process: nobody could run for parliament without belonging to a political party. In a country with a limited tradition of political expression and where civil society was still in its infancy, these measures were useful tools for generating political awareness and guaranteeing the spread of political knowledge among political activists.

The major drawback of this model is the distance it places between the people and their representatives. While formally the constituency of each deputy is the country as a whole, in practical terms they are answerable only to their parties. In addition, the design of the constituencies and the way in which parties fill their lists for the legislative elections effectively prevent the citizens from choosing individuals who will best serve as their representatives. Perhaps the internal democracy of the parties will offer an antidote to this malaise.

One possible threat of this model to the governability of the country lies in the hypothesis of one party securing a parliamentary majority and the other controlling the executive through the powers of the head of state. Such a situation could indeed have arisen after the general elections of 1994 and 1999 if the 'first-past-the-post' system had been adopted in the General Peace Agreement. 
The best possible solution might be a move to a semi-presidential system. This would entail the executive being responsible both to parliament and to the head of state, as indeed was the intention of the circulated draft for the revision of the state Constitution shortly before the 1999 elections.

\section{REFÉRENCES}

Beetham, D. and K. Boyle. 1995. Introducing Democracy: 80 Questions and Answers. Polity Press and UNESCO Publishing.

Carrilho, N. 1996. 'The electoral legislation in Mozambique and the political and social achievement'. In Brazão Mazula (ed). Elections, Democracy and Development. Maputo.

Lungarzo, C. 1989. O que são eleições. São Paulo, Brazil: Editora Brasiliense.

Monteiro, J. O. 1988. Poder e Democracia. Maputo: Assembleia Popular.

National Elections Commission. 1995. Final Report. Maputo, Mozambique, April.

Przeworski, A. 1991. Democracy and the market: Political and economic reforms in Eastern Europe and Latin America. Cambridge: Cambridge University Press.

Riker, W. H.1982. Liberalism Against Populism: A confrontation between the theory of democracy and the theory of social choice. Prospect Heights, Illinois: Waveland Press Inc.

Schumpeter, J. A. 1954. Capitalism, Socialism and Democracy. London: Ruskin House, George Allen \& Unwin Ltd.

Sitoe, E.1999. 'Noções e Questões do Parlamentarismo - o Parlamentarismo em Moçambique'. Maputo: Curso para Funcionários da Assembleia da República, (Unpublished document) Novembro de 1999.

Tollenaere, M De. 2000. 'Sustainable Electoral Democracy in Mozambique International Support and self-reliance'. Paper presented at the International IDEA Conference on 'Promoting Sustainable Democratic Institutions in Southern Africa', Gaborone, Botswana, 8-10 May. 